\title{
A new record of Desmarestia dudresnayi J.V. Lamouroux ex Léman (Desmarestiaceae, Heterokontophyta) represents a new southernmost limit of its distribution in the North Atlantic Ocean
}

María Altamirano, Elena Bañares \& Marianela Zanolla

Departamento de Biología Vegetal (Botánica). Facultad de Ciencias. Universidad de Málaga. Campus de Teatinos s/n. 29071 Málaga.

\section{Resumen}

Correspondence

M. Altamirano

E-mail: altamirano@uma.es

Received: 16 January 2014

Accepted: 4 April 2014

Published on-line: 16 May 2014
Un nuevo registro de Desmarestia dudresnayi J.V. Lamouroux ex Léman (Desmarestiaceae, Heterokontophyta) representa un nuevo límite meridional de su distribución en el Atlántico Norte

Este trabajo aporta la primera cita de Desmarestia dudresnayi (Phaeophyceae, Desmarestiaceae) para la provincia de Cádiz, que representa el registro más meridional de esta especie de hábitat profundo para las costas del Atlántico Norte. Se ha realizado una descripción morfológica del ejemplar encontrado.

Palabras clave: Corología, Estrecho de Gibraltar, Cádiz, España.

\begin{abstract}
This work reports the first record of Desmarestia dudresnayi (Phaeophyceae, Desmarestiaceae) for Cádiz province (Southern Spain), representing the southernmost record of this deep habitat species on the North Atlantic coast. Morphological description of the specimen is provided.
\end{abstract}

Key words: Chorology, Strait of Gibraltar, Cádiz, Spain.

\section{Introduction}

The order Desmarestiales includes sublittoral species distributed along polar to warm-temperate coasts (Peters \& Breeman 1992). The order includes four genera, Arthrocladia Duby, Himantothallus Skottsberg, Phaeurus Skottsberg and Desmarestia J.V. Lamouroux, the three former ones being monotypic. While Himantothallus and Phaerus are endemic to Antarctica and South Georgia, Arthrocladia and Desmarestia exhibit a wider distribution range and are both also present in the Northern Hemisphere.

The genus Desmarestia includes species widely distributed from Antarctica to the Arctic in polar to warm-temperate coasts. Its members are characterized by a heteromorphic life history with microscopic gametophytes, which after oogamous reproduction mediated by the sexual pheromone desmarestene bear macroscopic sporophytes. Thalli are erect and can be terete, compressed or ligulate, simple or branched, reaching several meters in length. Compared with the Laminariales, they differ in having a thallus of pseudoparenchymatous construction and trichothallic growth (reviewed in Peters et al. 1997).

Except for Desmarestia ligulata (Stackhouse) J.V. Lamouroux and Desmarestia viridis (O.F. 
Müller) J.V. Lamouroux, which are globally distributed and maybe locally common, most Desmarestia species are endemic to certain regions (Peters et al. 1997). D. dudresnayi, which encompasses Desmarestia tabacoides Okamura, Desmarestia patagonica Asensi, Desmarestia foliacea Pease and Desmarestia sivertsenii Baardseth, is also widely distributed in the Atlantic and Pacific Oceans (Yang et al. 2014), however it is usually rare. In the North Atlantic, it is considered endemic of the Lusitanic province with a warm-temperate distribution (Bárbara et al. 2005, 2006a; Yang et al. 2014), and some boreal relic populations in the Mediterranean Sea (Ribera et al. 1992, Rindi \& Cinelli 1995, Conde \& Flores-Moya 2000, Báez et al. 2001).

\section{Results and Discussion}

We present the southernmost record of $D$. dudresnayi on the North Atlantic coast, and the first record for Cádiz province. A drifted sporophyte of $40 \mathrm{~cm}$ length was found at Isla de Tarifa, Cádiz, Southern Spain (36 $06^{\circ} 09^{\prime \prime} N 5^{\circ} 36^{\prime} 44^{\prime \prime}$ ) $)$ on 28th October 2011. The non-branched blade exhibited a prominent main nerve with secondary nerves, with a leaf-like appearance. The herbarium sheet has been included in the University of Málaga Herbarium (MGC Phyc 5427; herbarium acronym follows Holmgren et al. 1990). At the time of collection, the thallus exhibited no damage, sugges- ting that the specimen originated from a nearby population. However, when preparing the herbarium sheet, part of the thallus became greenish due to discharge of the intracellular sulfuric acid (Sasaki et al. 1999)(Fig. 1).

Recent descriptions of gametophytes of $D$. $d u$ dresnayi describe it as monoecious, densely branched and 10-15 $\mu \mathrm{m}$ in diameter, becoming reproductive between 10 to $15^{\circ} \mathrm{C}$ (Yang et al. 2014). This annual species present marked seasonality revealed from studies on the maërl bed communities from north-west coast of Spain, where the species showed a maximum cover in summer and being absent in winter, at a depth interval from -3 to $-26 \mathrm{~m}$ depth (Bárbara et al. 2005, 2006b; Peña 2010). Despite this recent information on the biology of the species, the physiology and biochemistry of this species is still poorly understood (Yang et al. 2014).

\section{Acknowledgements}

This work has been developed in the framework of the projects "ALIAN" CGL2008/01549 (Ministerio de Ciencia e Innovación) and P09RNM-5187 (Consejería de Innovación, Ciencia y Empresa, Junta de Andalucía), and Research Fellowships from the Instituto de Estudios Ceutíes 2009 and 2010. Marianela Zanolla was supported by the Excellence Proyect P09-RNM-5187 from

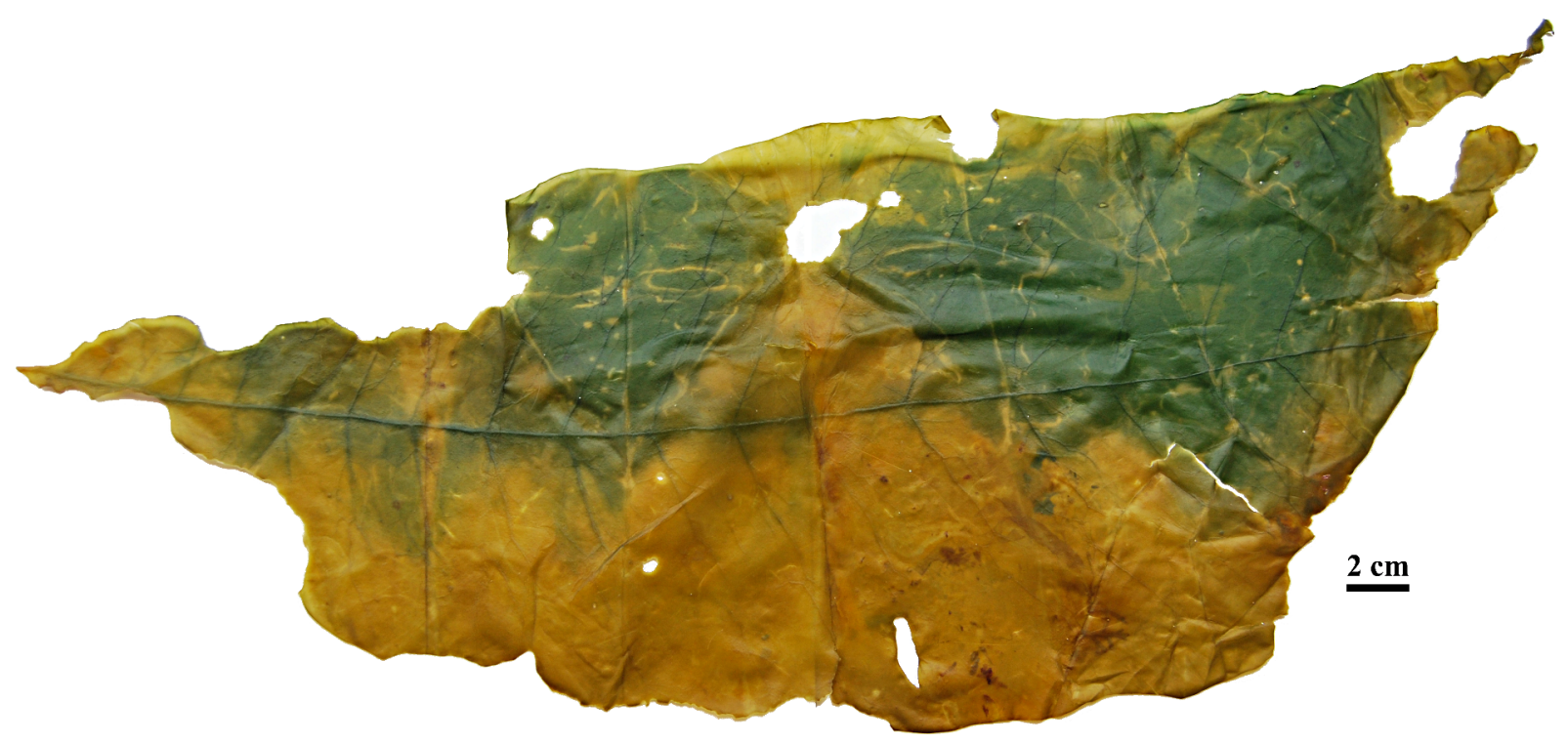

Figura 1. Ejemplar de Desmarestia dudresnayi encontrado en Tarifa, mostrando daño en el talo por compuestos ácidos. Figure 1. Specimen of Desmarestia dudresnayi found at Tarifa, exhibiting damage on the thallus by acid substances. 
the Consejería de Innovación, Ciencia y Empresa, Junta de Andalucía. We are grateful to Dr. A.F. Peters for confirming the identification of the species, reading and improving the present manuscript and, together with Dr. I. Bárbara and Dr. H. Kawai, for providing useful bibliographic references. The authors would like to thank the Office of Parque Natural de El Estrecho (Cádiz, Spain) and the Comandancia de la Guardia Civil at Tarifa for permitting access to Tarifa Island.

\section{References}

Báez JC, Conde F \& Flores-Moya A. 2001. Notas corológicas del macrofitobentos de Andalucía (España). V. Acta Bot. Malacitana, 26: 193-196.

Bárbara I, Cremades J, Calvo S, López-Rodríguez MC \& Dosil J. 2005. Checklist of the benthic marine and brackish Galician algae (NW Spain). Anal. J. Bot. Madrid, 62: 69-100.

Bárbara I, Díaz P, Cremades J, Peña V, López-Rodríguez MC, Berecíbar E \& Santos R. 2006a. Catálogo gallego de especies amenazadas y lista roja de las algas bentónicas marinas de Galicia. Bol. Inf. Soc. Esp. Ficol., 35: 9-19.

Bárbara I, Díaz P, Araújo R, Peña V, Berecibar E, Cremades J, Freire O, Baamonde $\mathrm{S}$, Novo T, Calvo $\mathrm{S}$, López-Rodríguez MC, Afonso-Carrillo J, De Clerck O, Santos R, Sousa-Pinto I, Tibaldo M, Lagos V, López C, Secilla A, Santolaria A, Díez I \& Veig AJ. $2006 \mathrm{~b}$. Adiciones corológicas y correcciones a la flora bentónica marina del norte de la Península lbérica. NACC Nova Acta Cient. Compostel., 15: 77-88.
Conde, F \& Flores Moya A. 2000. Nuevas adiciones al conocimiento de las macroalgas marinas de la isla de Alborán (Mediterráneo Occidental). Acta Bot. Malacitana, 25: 180-184.

Holgrem PK, Holgrem NH \& Barnett IC (1990) Index herbariorum. Part I: The herbaria of the world. Vol. 120. New York Botanical Garden, New York.

Peña V \& Bárbara I. 2010. Seasonal patterns in the maërl community of shallow European Atlantic beds and their use as a baseline for monitoring Studies. Eur. J. Phycol., 45: 327-342.

Peters AF \& Breeman A. 1992. Temperature responses of disjunct temperate brown algae indicate long-distance dispersal of microthalli across the tropics. J. Phycol.. 28: 428-438.

Peters AF, Van Oppen MJH, Wiencke C, Stam WT \& Olsen JL. 1997. Phylogeny and historical ecology of the Desmarestiaceae (Phaeophyceae) support a southern hemisphere origin. J. Phycol., 33: 294-309.

Ribera MA, Gómez-Garreta A, Gallardo T, Cormaci M, Furnari G \& Giaccone G.1992. Check-list of Mediterranean Seaweeds. I. Fucophyceae (Warming 1884). Bot. Mar., 35: 109-130.

Rindi F \& Cinelli F. 1995. Contribution to the knowledge of the benthic algal flora of the Isle of Alboran, with notes on some little-known species in the Mediterranean. Crypt. Algol., 16: 103-114.

Sasaki H, Kataoka H, Kamiya M \& Kawai H. 1999. Accumulation of sulfuric acid in Dictyotales (Phaeophyceae): taxonomic distribution and ion chromatography of cell extracts. J. Phycol., 35: 732-739.

Yang EC, Peters AP, Kawai H, Stern R, Hanyuda T, Bárbara I, Müller D, Strittmatter M, Prud'Homme van Reine WF \& Küpper FC. 2014. Ligulate Desmarestia (Desmarestiales, Phaeophyceae) revisited: D. japonica sp. nov. and D. dudresnayi differ from D. ligulata. J. Phycol., doi:10.1111/jpy.12148. 